\title{
Małgorzata Jankowska Współczesna apokryficzność. Próba kulturoznawczej analizy zjawiska
}

\begin{abstract}
Jankowska Małgorzata, Współczesna apokryficzność. Próba kulturoznawczej analizy zjawiska [Modern apocrypha: An attempt at cultural analysis]. „Przestrzenie Teorii” 23. Poznań 2015, Adam Mickiewicz University Press, pp. 71-90. ISBN 978-83-232-2920-9. ISSN 1644-6763. DOI 10.14746/pt.2015.23.5
\end{abstract}

The aim of this paper is to analyze the phenomenon of modern apocrypha from the perspective of cultural studies. The term 'apocrypha' is usually associated with early Christian and Gnostic texts, but the tradition of unorthodox writings is also continued in modern Western culture. It is not easy to formulate a comprehensive definition of apocrypha by analyzing this phenomenon only from the perspective of literary, historical and religious studies. The phenomenon of apocrypha is so complex that it should be described based on a kind of methodological bricolage. This method should allow one to understand the role that apocrypha play in modern culture. Many scholars have noticed that it is not possible to point to clear and obvious criteria that would allow us to assign a given text to the category of apocryphal writings. Most typologies of texts which are epistemologically valuable and which help scholars to identify certain features of apocryphal writings do not take into consideration the cultural qualities of non-canonical, unorthodox narratives. From the perspective of cultural studies, modern apocrypha can be seen not only as literary or religious texts but also as an important element of cultural autocommunication. As an element of cultural metacognition, apocrypha can also be regarded as a medium of cultural memory and collective identity.

Apokryficzność jest zjawiskiem o długiej i burzliwej historii, do tego złożonym i nieoczywistym. Pojęcie apokryfu łączy się, rzecz jasna, głównie z piśmiennictwem wczesnochrześcijańskim i gnostyckim, jednak tradycja nieortodoksyjnych ${ }^{1}$ odczytań kanonu pozostaje żywa. Współczesna kultura Zachodu ${ }^{2}$ obfituje w różnego typu nowatorskie interpretacje czy „uzupełnienia” mitów źródłowych, przy czym nawiązania te przyjmują rozmaite formy: od tekstów literackich i filozoficznych, przez sztuki wi-

${ }^{1}$ Rozumianych czy postrzeganych jako takie przez daną instytucję religijną, „strażnika kanonu", który ustala jakąś wykładnię ortodoksyjną. Pojęcie nieortodoksyjności jest zatem każdorazowo zrelatywizowane do takiej właśnie wykładni, a więc względne i kulturowo oraz historycznie zmienne.

${ }^{2}$ Pojęcie „kultury Zachodu” jest, rzecz jasna, swoistą idealizacją, przez którą rozumie się tutaj głównie dziedzictwo kultur starożytnej Grecji i Rzymu oraz kultury judeochrześcijańskiej, będzie to zatem, znów - w przybliżeniu czy uproszczeniu, na wysokim poziomie ogólności rozumiana kultura europejska i północnoamerykańska. Termin ten nie zdaje sprawy z licznych różnic etnicznych, wyznaniowych itp., nie są one bowiem istotne dla prowadzonych tu rozważań. 
zualne (filmy, instalacje artystyczne, seriale telewizyjne czy teledyski), po twórczość internetową (jak przykładowo fan fiction czy memy). Równie szeroka jest ich rozpiętość problematyczna - służą one rozważaniom tak teologicznym, jak i filozoficznym, religioznawczym, socjologicznym czy politycznym. „Współczesne apokryfy” propagują też rozmaite, skrajnie zróżnicowane wizje świata oraz różnorodne idee - od prób „oddolnego ewangelizowania”, przez apoteozę religijności sprywatyzowanej, po pochwałę scjentystycznie pojmowanego racjonalizmu, a dalej - od gorliwej wiary, przez zwątpienie, po agnostycyzm czy wojujący ateizm.

Czy te współczesne, tak zróżnicowane w formie, treści i celach teksty kultury można w ogóle określić mianem apokryfów? Jak ukazać ich odmienność na tle tradycyjnego piśmiennictwa apokryficznego? Odpowiedź na tak postawione pytania stać się może zaczynem szerszej kulturoznawczej refleksji nad rolą, jaką rozmaite nieortodoksyjne odczytania kanonu pełnią we współczesnej kulturze Zachodu. Wyjście poza historyczne, literaturoznawcze czy religioznawcze ustalenia i umieszczenie problemu apokryficzności w szerszym kulturowym kontekście pozwoli, jak sądzę, na dostrzeżenie funkcji, jaką pełni ona $\mathrm{w}$ procesach pielęgnowania pamięci kulturowej i, co za tym idzie, w mechanizmach kształtowania tożsamości zbiorowej. Dopiero analiza tak postawionych problemów umożliwi pogłębiony ogląd zjawiska, pozwalając tym samym na jego (wciąż zapewne niewyczerpujące) dookreślenia i analizy.

\section{Tradycyjne apokryfy}

Apokryf to termin trudny do zdefiniowania, niełatwo bowiem stworzyć jasne kryteria, które pozwoliłyby na wyczerpującą jego charakterystykę. Jak pisze Marek Starowieyski, „sprawa określenia terminu apokryf jest [...] ciągle daleka od ostatecznego rozwiązania"3. Warto jednak pokusić się o krótkie podsumowanie dotychczasowych ustaleń i definicji, które posłużyć mogą za punkt wyjścia do dalszych kulturoznawczych analiz. Mały słownik teologiczny mianem apokryfów określa:

(utajone, tajemne) księgi, które z powodu fantastycznej treści, niewiadomego pochodzenia czy z tej racji, że ich autorami byli heretycy, nie były wykorzystywane w liturgii i teologii i pomimo żydowskiego, względnie chrześcijańskiego, częściowo wczesnego pochodzenia nie zostały włączone do kanonu Pisma Świętego. Apokryfy Starego Testamentu (w teologii katolickiej w znacznym stopniu identyczne z późnojudaistyczną apokaliptyką) zostały określone przez teologię ewangelicką jako pseudoepigrafy. Przez apokryfy Starego Testamentu rozumie teo-

${ }^{3}$ M. Starowieyski, Barwny świat apokryfów, Poznań 2006, s. 7. 
logia ewangelicka najczęściej tzw. „księgi deuterokanoniczne”. Przez apokryfy Nowego Testamentu (Ewangelie apokryficzne, apokryficzne Dzieje Apostolskie, Listy i Apokalipsy; ilościowo jest ich bardzo wiele [...]) teologia katolicka i ewangelicka rozumie to samo ${ }^{4}$.

Wyróżnia się tu trzy podstawowe cechy apokryficzności - „fantastyczną treść”, heretycki charakter oraz trudne do określenia pochodzenie. Nie są to jednak własności wystarczające do stworzenia wyczerpującej definicji, stąd też wyróżnia się pewne kryteria dodatkowe. Pierwszym z nich jest „tajemniczy charakter” tekstu. Na tę własność zwracają uwagę głównie ci badacze, których analizy zorientowane są na etymologię greckie słowo apokryphos oznacza bowiem „ukryty”. Po raz pierwszy użyte zostało przez Orygenesa w odniesieniu do ksiąg gnostyckich, w samych apokryfach praktycznie się jednak nie pojawia (wyjątkiem są tu dwa teksty z Nag Hammadi - Apokryfon Jana oraz List apokryficzny Jakuba) ${ }^{5}$. Problem ten podejmuje między innymi szwedzki badacz Per Beskow:

odkąd ludzie opanowali sztukę czytania i pisania, nie przestają fascynować się możliwością dokonania sensacyjnego odkrycia nieznanego tekstu. W starożytnej literaturze egipskiej, greckiej i rzymskiej znajdujemy bogactwo opowieści o księgach i listach: bądź to spadłych z nieba, bądź odnalezionych w grobowcach, świątyniach czy starych bibliotekach, a zawierających rozmaite objawienia, proroctwa oraz magiczne receptury ${ }^{6}$.

Motyw tajemniczej księgi odnosi się, rzecz jasna, do tradycyjnej symboliki słowa pisanego, związanej z mądrością, nauką, pamięcią, prawdą, a także magią, wiedzą tajemną czy proroctwem. Pojawia się on zresztą także w Piśmie Świętym, co pozwala dostrzec ciekawą relację kanonu i odstępstwa w przestrzeni symbolicznej7. Apokryficzność w tym rozu-

${ }^{4}$ K. Rahner, H. Vorgrimler, Mały słownik teologiczny, przeł. T. Mieszkowski, P. Pachciarek, Warszawa 1987, s. 19.

${ }^{5}$ M. Starowieyski, Barwny świat apokryfów, s. 6.

${ }^{6}$ P. Beskow, Osobliwe opowieści o Jezusie. Analiza nowych apokryfów, przeł. J. Wolak, wstęp M. Starowieyski, Kraków 2005, s. 15.

7 Księga, w której zapisywane są wszelkie ludzkie uczynki, tak dobre, jak i złe, stanowić ma podstawę Boskich wyroków (por. choćby Ne 13,14, Iz 65,6-7, Ps 56,9, Ps 69,29, Dn 7,10, Ap 3,5, Ap 13,8, Ap 17,8, Ap 20,12). Tajemniczy tekst stanowi tutaj metaforę absolutnej pamięci, której nic nie umyka. Warto tu zauważyć, że księga jako metafora pamięci funkcjonowała także w tradycjach antycznych Grecji oraz Rzymu (np. u Cycerona), a także później, w średniowiecznych tradycjach monastycznych i scholastycznych (jako podpora pamięci, element mnemotechniki). Szerzej pisze o tym D. Draaisma w książce Machina metafor. Historia pamięci (przeł. R. Pucek, Warszawa 2009, zwłaszcza strony 41-75), a także A. Kamieńska w Twarzach księgi (Warszawa 1982).

W Piśmie Świętym pojawiają się wzmianki również o księgach pogańskich, jak choćby w Dziejach Apostolskich, w których niszczenie innowierczych tekstów równa się zwycię- 
mieniu stanowiłaby swoistą „zmianę paradygmatu”, czyli odejście od kanonu w stronę kolejnych interpretacji czy objawień. Zgodnie z etymologią przejście to wiązać by się miało $\mathrm{z}$ wtajemniczeniem, $\mathrm{z}$,wiedzą dla wybranych". Starowieyski zauważa jednak, że apokryfy cieszyły się zawsze dużą popularnością, stąd ich „tajemniczość” to swoisty mit, a tym samym słabe kryterium wyróżniające je spośród innych tekstów.

Drugą cechą charakterystyczną apokryfów jest pseudonimia, czyli przypisywanie autorstwa danego tekstu konkretnej postaci staro- lub nowotestamentowej (przykładem mogą być ewangelie podpisywane imionami apostołów czy Marii Magdaleny). Jak jednak zauważa Ryszard Rubinkiewicz, jest to swego czasu praktyka powszechna, a jej ślady odnaleźć można nie tylko w apokryfach, ale i w samym Piśmie Świętym (jako przykład wskazuje się m.in. Pięcioksiąg, którego ostateczna redakcja nastąpiła dopiero w V wieku przed Chrystusem, a który w całości postrzegany jest jako dzieło Mojżesza) ${ }^{8}$. Badacz, za L.H. Brockingtonem, wymienia podstawowe źródła popularności pseudonimii, a są to: „bezczasowa koncepcja myśli żydowskiej, która pozwalała przenikać epoki poprzez wszystkie pokolenia; stosowanie pseudonimii przy proklamowaniu kodeksów legislacyjnych [...]; wysuwanie Prawa przed wszystkie inne formy objawienia; wygasanie instytucji proroctwa; zainteresowanie Żydów sprawami spoza świata widzialnego"9. Starowieyski z kolei pokazuje, że pseudoepigrafia (pseudonimia) związana jest nie tylko z kulturą żydowską, ale i wczesnochrześcijańską, co wynika z faktu, iż „w starożytności chrześcijańskiej i żydowskiej, a także klasycznej, nie istniało prawo do nazwiska (czy imienia) i podpisywanie utworu imieniem jakiejś sławnej osoby było powszechną praktyką i tylko zwiększało autorytet danego dzieła. Każdy podręcznik starożytnej literatury greckiej zawiera wiele utworów poprzedzonych słowem Pseudo- (Ps. Platon, Ps. Lukian, Ps. Arystoteles, Ps. Jan Chryzostom itd.). Jeśli więc mamy utwory figurujące pod imieniem Apostoła jako autora, to jego autorstwo świadczy o autorytecie Apostołów w tym czasie oraz dodawało utworowi większego znaczenia"10. Tego typu fałszerstwo nie jest zatem kryterium wystarczającym do określenia danego tekstu mianem apokryfu.

stwu misji ewangelizacyjnej św. Pawła w Efezie: „I wielu też z tych, co uprawiali magię, poznosiło księgi i paliło je wobec wszystkich” (Dz 19,19). Również i tu księgi symbolizują wiedzę tajemną, z tą wszakże różnicą, że fatszywą. Ich niszczenie to symbol przemiany kulturowej - objawienie przynosi nową moralność i nowe prawo.

8 R. Rubinkiewicz, Wprowadzenie do apokryfów Starego Testamentu, Lublin 1987, s. $11-12$.

9 Tamże, s. 14.

${ }^{10}$ M. Starowieyski, Barwny świat apokryfów, s. 9. 
Podobnie rzecz ma się z czasem powstania tekstów apokryficznych. Jak wskazuje Starowieyski, istnieje duże prawdopodobieństwo, że niektóre z nich datować można tak samo jak wybrane teksty Nowego Testamentu. Przywołuje się tu często słowa św. Pawła, który ostrzega obywateli Tessalonik przed fałszerzami, powołującymi się na rzekome natchnienie Duchem Świętym: „W sprawie przyjścia Pana naszego Jezusa Chrystusa i naszego zgromadzenia się wokół Niego, prosimy was, bracia, abyście się nie dali zbyt łatwo zachwiać w waszym rozumieniu ani zastraszyć bądź przez ducha, bądź przez mowę, bądź przez list, rzekomo od nas pochodzący, jakoby już nastawał dzień Pański” (2 Tes 2,1-2). Starowieyski zauważa nadto, że ,jeżeli Didache zawierająca naukę, którą miało przekazać dwunastu Apostołów - a więc w jakiś sposób może być uznana za apokryf typu prawnego [...] - została spisana w latach 60. do 120 , to mogła powstać nawet przed niektórymi pismami Nowego Testamentu [wyr. - M.J.], jak Ewangelia czy Apokalipsa Janowa"11. Za najpłodniejszy apokryficznie okres uważa się II i III wiek, jednak w każdej kolejnej epoce pojawiały się tego typu teksty. Podobnie zróżnicowany jest czas „odnalezienia” - Beskow zauważa, że pragnienie odkrycia tajemniczego tekstu odnotowuje już literatura starożytnego Egiptu czy Grecji. Współcześnie także napotyka się doniesienia o kolejnych sensacyjnych odkryciach, tak faktycznych, jak i fałszywych (np. prawdziwe odkrycia związane z koptyjsko-gnostycką biblioteką w Nag Hammadi czy odnalezienie zwojów znad Morza Martwego, fałszywe „odkrycie” niektórych fragmentów Ewangelii pokoju, zwanej esseńską 12 ).

Wyróżniki gatunkowe stanowią równie słabe kryterium, apokryfy sa bowiem tekstami wyjątkowo pod tym kątem zróżnicowanymi - znaleźć wśród nich można tak ewangelie, listy czy proroctwa, jak i inne formy poetyckie czy prozatorskie. Podobnie zróżnicowana jest stylistyka, zależna m.in. od czasu i miejsca powstania. Apokryfy późniejsze często wzorowane są nie tyle na kanonie, ile na apokryfach wcześniejszych, inne naśladują styl Pisma Świętego (psalmy i ewangelie), są też i takie, które proponują własny, oryginalny sposób przekazu.

Powody, dla których pisano apokryfy, są równie różnorodne jak ich stylistyka ${ }^{13}$. Wśród najważniejszych wymienia się: (1) chęć propagowania treści konkurencyjnych w stosunku do kanonu, (2) potrzebę egzegezy (objaśniania treści kanonicznych w sposób dostosowany do danego czasu, miejsca i kompetencji wspólnoty) oraz (3) kontynuację tradycji ustnej (spisanie przekazów wciąż obecnych $\mathrm{w}$ uniwersum kultury, mimo już

11 Tamże, s. 11-12.

12 P. Beskow, Osobliwe opowieści o Jezusie, s. 22.

${ }_{13}$ M. Starowieyski, Barwny świat apokryfów, s. 14-19. 
uformowanego kanonu Ewangelii - ośrodkiem tej tradycji jest postać Jezusa i związane z nią wydarzenia, przemowy i świadectwa, z których nie wszystkie weszły w skład Nowego Testamentu, znajdując później miejsce właśnie $\mathrm{w}$ apokryfach. Uznaje się, że w tego typu tekstach odnaleźć można informacje prawdziwe, choć zdeformowane przez długookresowy przekaz ustny i zmieszanie z późniejszymi, odmiennymi tradycjami). Dużą rolę odgrywa również (4) żydowska teologia obrazowa z jej bogactwem językowym i rozbudowaną metaforyką. Apokryfy byłyby zatem również „wyrazem pierwotnej teologii chrześcijańskiej, zazwyczaj judeochrześcijańskiej, jeszcze nie przepuszczonej przez sita logiki greckiej i uporządkowanej za pomocą ścisłych terminów teologicznych"14. Ważnym czynnikiem jest w końcu (5) ludzka ciekawość, potrzeba wypełnienia białych plam kanonu: „Kim była Maryja: jakie było jej pochodzenie i jaki kres? Kim był św. Józef? Jakie było dzieciństwo Jezusa? Jak wyglądała ucieczka do Egiptu i co On tam porabiał? Jakie były okoliczności śmierci Jezusa? Jak to było z Jego wstąpieniem do otchłani? [...] Takich pytań było bardzo wiele i na nie szukano odpowiedzi"15.

Widać wyraźnie, że żadne z tych kryteriów nie wyczerpuje „fenomenu apokryfu". Badacze są jednak zgodni, że najważniejszą własnością, stanowiącą niejako ramę dla pozostałych, jest niekanoniczność. Starowieyski, analizując etymologię, dochodzi do wniosku, że skoro apokryfy były, o czym wspomniano, tekstami intensywnie rozpowszechnianymi, to słowo apocryphos musi wiązać się z czymś innym niż ich tajemniczy charakter. Przyczyn błędnego łączenia „skrytości” z niedostępnością badacz upatruje w nieprzystawalności semantycznej terminów hebrajskiego i greckiego. Grecki odpowiednik zubaża, jego zdaniem, hebrajski oryginał, czyli słowo ganuz ${ }^{16}$, oznaczające nie tylko skrytość, ale i wyłączenie. O ile pierwsze znaczenie bliskie jest apocryphos, o tyle drugie otwiera nowe możliwości interpretacji, wyłączenie bowiem rozumieć można w dwójnasób. To zarówno „wyłączenie z kultu przez zużycie - święte księgi wyłączone z kultu ze względu na ich zniszczenie składano w genizie, czyli schowku, znajdującym się przy synagodze"17, jak i wyłączenie ze względu na szkodliwość (niekanoniczność). Wyłączenie z kanonu ma, rzecz jasna, różne przyczyny, jednak wyróżnia się wśród nich przede wszystkim heretycki czy skandaliczny charakter danego tekstu.

14 Tamże, s. 17.

15 Tamże, s. 19.

${ }^{16}$ Apokryfy Nowego Testamentu. Ewangelie apokryficzne, cz. I: Fragment. Narodzenie i dziecinstwo Maryi i Jezusa, red. M. Starowieyski, Kraków 2003, s. 21.

17 Tamże. 
Bazując na tych etymologicznych analizach, Starowieyski proponuje dwa rozumienia terminu apokryf ${ }^{18}$. Znaczenie (1) biblijne, czy też techniczno-kościelne, oznacza sprzeczność z kanonem Pisma Świętego. Tu pojawia się nadto rozróżnienie na (a) „utwór o tematyce biblijnej, nie zawarty w kanonie Starego i Nowego Testamentu" (rozumienie wspólne dla teologii katolickiej i protestanckiej) oraz na (b) określane w protestantyzmie mianem apokryfów, a w katolicyzmie mianem ksiąg deuterokanonicznych księgi Starego Testamentu, wykluczone z kanonu żydowskiego. W (2) znaczeniu potocznym natomiast apokryf to po prostu sfałszowany, nieautentyczny tekst o tematyce biblijnej.

\section{Narracje apokryficzne}

W obszar tej drugiej (potocznej) definicji wpisać można teksty, które określam mianem współczesnych narracji apokryficznych. Rzecz jasna apokryfy tradycyjne są również narracjami, tak w klasycznym, literaturoznawczym sensie, jak i w rozumieniu nauk humanistycznych, w pojęciu narracji upatrujących klucza do analizy jednostkowych i zbiorowych sposobów opowiadania i rozumienia siebie oraz świata. Dlatego też przeprowadzić należy bardziej szczegółowe rozróżnienia między wczesnochrześcijańskimi i gnostyckimi egzegezami Pisma Świętego a współczesnymi (re)interpretacjami kanonu.

Starowieyski podkreśla, że zbiór tekstów apokryficznych nie jest jeszcze ostatecznie zamknięty. I choć, rzecz jasna, współczesność danego tekstu jest pewną wskazówką, pozwalającą zaklasyfikować go raczej do zbioru narracji apokryficznych niż tradycyjnych apokryfów, to pamiętać należy, że czas powstania tych drugich jest wielce zróżnicowany, zatem nie byłoby to kryterium wystarczające. Mimo tych i innych trudności klasyfikacyjnych można jednak, jak sądzę, nakreślić linie graniczne między oboma wspomnianymi zbiorami tekstów.

Ważną cechą, odróżniającą apokryfy tradycyjne od narracji apokryficznych, jest cel fałszerstwa. O ile te pierwsze udają świadectwa, o ile wyraża się $\mathrm{w}$ nich dążenie do przekonania odbiorcy o autentyczności przekazu (faktycznym autorstwie postaci biblijnej, faktycznym objawieniu), o tyle te drugie posługują się iluzją fałszerstwa, będącą wyłącznie elementem stylizacji, grą z konwencjami kulturowymi. Podobnie rzecz ma się z „drugim poziomem” fałszerstwa, czyli rzekomym odnalezieniem tajemniczego tekstu - w przypadku tradycyjnego apokryfu jego „starożytnośćc to element uwiarygodniający, w przypadku narracji apo-

18 Tamże, s. 20. 
kryficznej zaś to jedynie wprowadzenie do stylizacji, sugerowanie kodu kulturowego, za pomocą którego należy tekst odczytywać. Ten w sumie rzadko pojawiający się zabieg bardziej zatem podkreśla fikcyjność narracji apokryficznej, niż ją kamufluje. W obu przypadkach - apokryfów tradycyjnych i współczesnych narracji apokryficznych - chodzi, rzecz jasna, o pewne praktyki „ujawniania” tego, co skryte lub pominięte w kanonie, nadrzędny cel fałszerstwa jawić się zatem może jako ten sam. Jednak wszystkie zastosowane w obu typach tekstów zabiegi czy chwyty (transpozycje tematyczne, stylistyczne, retoryczne) mają na celu, jak się zdaje, realizację odmiennych strategii - rzekomego objawienia w przypadku wielu (acz, co należy zaznaczyć, nie wszystkich) apokryfów tradycyjnych oraz intertekstualnej czy intersemiotycznej gry w przypadku „apokryfów współczesnych".

Kolejną cechą pozwalającą rozróżnić oba typy tekstów jest stosunek do własnej literackości. W przypadku tradycyjnych apokryfów jest ona kolejnym elementem fałszerstwa - naśladując kanon, autorzy wykorzystują jego bogactwo gatunkowe, słownik i stylistykę. Jednak, udając dokumenty, apokryfy tradycyjne literackość czynią wartością drugorzędną, posługując się nią, znowu, dla uwiarygodnienia treści. W będących stylizacjami narracjach apokryficznych natomiast literackość jest elementem nad wyraz istotnym, co z kolei sprawia, że uwypuklona zostaje rola autora jako twórcy pomysłu i mistrza słowa. To znacząca różnica z jednej strony mamy figurę świadka, posłańca, tuby, przez którą przemawia Bóg, z drugiej zaś mocno widocznego pisarza-artystę, mówiącego własnym głosem. To z kolei prowadzi do kolejnej istotnej różnicy, ujawniającej się już nie w formie, a w treści. Oba typy tekstów wykorzystują postaci, wątki i symbole zaczerpnięte z Pisma Świętego, jednak o ile tradycyjne apokryfy są „próbą ewangelizacji” (choćby i heretyckiej), o ile przekazują „prawdy objawione”, o tyle narracje apokryficzne nawiązują do kanonu z pozycji dystansu, raczej stawiając pytania, niż dając odpowiedzi. W przypadku tych drugich tematyka religijna staje się zresztą często jedynie pretekstem do rozważań nad zagadnieniami z zupełnie innych obszarów, jak choćby filozofia, polityka czy kultura. Na tę kwestię zwraca uwagę również Stanisław Balbus, który apokryficzność postrzega nieco szerzej, jako strategię intertekstualną czy intersemiotyczną (co zresztą w dużej mierze zgadza się z pewnymi intuicjami Jurija Łotmana, o których szerzej nieco dalej). Strategia owa zasadza się, w skrócie rzecz ujmując, na tym, że pierwotne signifié (zaczerpnięte $\mathrm{z}$ kanonu, tekstu źródłowego, mitu, innego dzieła literackiego itp.) staje się signifiant dla nowego (aktualnego, współczesnego) signifié. Powstaje wówczas metatekstualny palimpsest, w którym przez dwupiętrowy tekst przebija ślad 
„oryginału”, tekstu źródłowego' ${ }^{19}$. Badacz zauważa, że każda taka transpozycja pierwotnego tematu, znaku czy symbolu jest wobec oryginału z konieczności niewierna czy przekłamana (a jeśli owo przekłamanie przybiera postać wyjątkowo intensywną, wówczas mamy do czynienia z parodią czy pastiszem ${ }^{20}$. Balbus o takim wykorzystywaniu oryginalnych motywów czy symboli dla obrazowania problemów i zagadnień odmiennych od tych, które są przedstawione w tekście źródłowym, pisze: „Transponowany temat tradycji bywa [...] tutaj w wielu wypadkach niejako intertekstualnym pretekstem [...]. Oczywiście - transpozycja ma w takich przypadkach zawsze charakter apokryficzny"21. Może zatem, jak wspomniano, ów kanoniczny temat, motyw czy symbol stanowić jedynie punkt wyjścia, pretekst czy signifiant dla kolejnych kwestii, odległych od problematyki źródłowej.

Najważniejsza własność apokryfów, niekanoniczność, jest również kryterium różnicującym omawiane typy tekstów. O ile apokryfy tradycyjne chcą być tekstami świętymi, aspirują do kanonu, choć zostają $\mathrm{z}$ niego wykluczone, o tyle narracje apokryficzne uznają jego zamknięcie i odnoszą się doń wyłącznie intertekstualnie. By jednak zrozumieć lepiej tę różnicę, dookreślić należy samo pojęcie kanonu.

Zagadnienia związane $\mathrm{z}$ kanonicznością dogłębnie analizuje Jan Assmann, niemiecki badacz, który, nawiązując do etymologii (starogreckie słowo kanôn oznacza linijkę, pręt ze skalą, narzędzie do pomiaru ${ }^{22}$ ), stwierdza pokrewieństwo kanonu $\mathrm{z}$ takimi pojęciami, jak kryterium, wzór, norma oraz lista. To ukontekstowienie pozwala na dookreślenie naczelnych cech kanonu, którymi są ścisłość, nienaruszalność i zamknięcie. Cechy te znajdują swoje odzwierciedlenie w czterech figurach/strategiach, symbolizujących kanoniczność w obszarze społecznej komunikacji. Są to: świadek (możliwie wierny komunikat o wydarzeniach), posłaniec (przekaz wiadomości z możliwie wiernym oddaniem sensu komunikatu), kopista (oddany słowo w słowo przekaz tekstu) oraz umowa (dokładne ustalenie i stosowanie nakazów i zakazów) ${ }^{23}$. Wspomniane strategie odzwierciedlają uspójniającą rolę kanonu, a także jego tendencje uniwersalistyczne - mówi on o początkach świata i danej zbiorowości (świadectwo), wyjaśniając zarazem ich głęboki sens (posłaniec), a podając wiernie objawienia (kopista), staje się automatycznie zbiorem praw, norm i zakazów (umowa).

19 S. Balbus, Między stylami, Kraków 1993, s. 349.

20 Tamże, s. 350.

21 Tamże, s. 357.

22 J. Assmann, Pamięć kulturowa. Pismo, zapamiętywanie i polityczna tożsamość w cywilizacjach starożytnych, przeł. A. Kryczyńska-Pham, Warszawa 2008, s. 121.

23 Tamże, s. 118-119. 
Assmann zauważa jednak, że wraz z teologizacją kanonu punkt ciężkości przesuwa się z tego, co właściwe, na to, co święte, przez co każda próba ingerencji wiązać się zaczyna $\mathrm{z}$ herezją. Odnosząc się ponownie do etymologii, badacz zauważa, że kanon jako „podziałka” oddzielać zaczyna ortodoksję od apokryfu24. Kanon staje się zatem rezerwuarem „świętego dziedzictwa tradycji; świętego zarówno w sensie absolutnego autorytetu i obligatoryjności, jak i nienaruszalności, która oznacza, że niczego nie można dodać, ująć ani zmienić”25.

Jednak jak każdy zapis, również i kanon, by stać się tekstem w pełnym znaczeniu, potrzebuje komentarza. Istotną rolę odgrywać zaczyna interpretacja i egzegeza: „obcowanie z kanonem wymaga udziału osoby trzeciej, interpretatora, który pośredniczyłby między tekstem a jego odbiorcą, uwalniając zawarte $\mathrm{w}$ literach impulsy normatywne i formatywne. Teksty należące do kanonu objawiają swój sens tylko wtedy, gdy zachodzi współdziałanie w triadzie: tekst - interpretator - odbiorca"26. Interpretacja jednak jest zawsze relatywizowaniem analizowanych treści do czasu, miejsca i wspólnoty. Na ten aspekt wskazuje również Paul Ricoeur, stwierdzając, że „znaczenie tekstu jest każdorazowo wydarzeniem, rodzącym się w punkcie przecięcia z jednej strony ograniczeń, jakie tekst niesie w sobie [...], a z drugiej rozmaitych oczekiwań kolejnych czytających i interpretujących go wspólnot, których nie mogli przewidzieć domniemani autorzy rozważanego tekstu"27. Interpretacje, odczytania i nawiązania do kanonu mogą przyjmować różne kształty. Assmann wyróżnia trzy podstawowe - komentarz, naśladownictwo i krytykę ${ }^{28}$. Strategie te odnaleźć można właśnie we współczesnych narracjach apokryficznych, i w tym upatruję ich swoistość, to właśnie bowiem poprzez te zabiegi umacniają one wizerunek kanonu jako tekstu zamkniętego. Nie są one ani wyrazem aspiracji do wejścia w poczet tekstów świętych, ani do stworzenia odrębnego, nowego kanonu. Rzecz jasna nie są to klasyczne zabiegi egzegetyczne, objaśniające znaczenia, każdorazowo bowiem, prócz ujawniania bogatych warstw semantycznych tekstu źródłowego, dodają znaczenia własne. Są to w pełnym znaczeniu teksty nowe. Najistotniejsze jednak jest to, że pozostają właśnie wyłącznie w relacji intertekstualności, nie aspiracji, i to odróżnia je najmocniej od apokryfów tradycyjnych.

24 Tamże, s. 140.

25 Tamże, s. 133.

26 Tamże, s. 110.

27 P. Ricoeur, A. LaCocque, Myśleć biblijnie, przeł. E. Mukoid, M. Tarnowska, Kraków 2003, s. 7.

28 J. Assmann, Pamięć kulturowa..., s. 117. 


\section{Kulturotwórcza rola współczesnej apokryficzności}

Wspomniane intertekstualne nawiązania do kanonu, jeśli poddać je analizie semiotycznej, mogą być postrzegane jako efekt tak zwanego twórczego przekładu. Zagadnienie to wnikliwie analizuje Jurij Łotman, przedstawiciel tartusko-moskiewskiej szkoły semiotyki kultury. Zdaniem Łotmana, idealna przekładalność jednego tekstu na drugi możliwa jest wyłącznie w językach formalnych. Każdy inny system znakowy, jako posiadający warstwę semantyczną, pozostaje swoisty i przez to nie poddaje się dokładnej translacji29.

Twórczy przekład generuje zatem nowe teksty, sensy i znaczenia, co wynika, jak wspomniano, z nieprzekładalności języków i/lub systemów semiotycznych (co z kolei ma źródło w nieprzystawalności leżących u ich podstaw kodów). Co istotne, jeśli komunikat źródłowy operuje tychże kodów mnogością, to otwiera się przestrzeń nie dla jednego nowego tekstu (przekładu), lecz dla wielu. Współczesne narracje apokryficzne postrzegać można właśnie jako efekt tego typu „translacji” - kanon byłby w tym przypadku bogatym w liczne kody tekstem wyjściowym, „apokryfy” zaś nowymi komunikatami, próbami „przełożenia” narracji źródłowej na język współczesnej kultury, na język odmiennych systemów znakowych.

Łotman zauważa, że nowy komunikat jest intensywnie „zorientowany na kod”, co prowadzi częstokroć do „semantycznego spłaszczenia” narracji źródłowej: „wzrost związków syntagmatycznych wewnątrz przekazu przygłusza pierwotne związki semantyczne i tekst na określonym poziomie odbioru może zachowywać się jako zbudowany w sposób złożony asemantyczny komunikat" 30 . W odniesieniu do interesującej nas relacji

${ }^{29}$ „[...] zamiast ścisłej odpowiedniości tekstowi T1 mamy pewną przestrzeń. Wszelki $\mathrm{z}$ wypełniających tę przestrzeń tekstów $\mathrm{t} 1, \mathrm{t} 2, \mathrm{t} 3, \ldots$, tn będzie możliwą interpretacją wyjściowego tekstu. Zamiast ścisłej odpowiedniości - jedna z możliwych interpretacji, zamiast symetrycznego przekształcenia - asymetryczne, zamiast tożsamości ekwiwalentów składających się na T1 i T2 - umowna ich ekwiwalencja. [...] Powstający w tych wypadkach tekst będziemy rozpatrywać jako nowy, a stwarzający go akt przekładu - jako twórczy [wyr. - M.J.]”. J. Łotman, Uniwersum umystu. Semiotyczna teoria kultury, przeł. B. Żyłko, Gdańsk 2008, s. 73.

30 Tamże, s. 89. „[...] jeśli [mity] od początku swego poczęcia miały określoną semantykę, to później związki te zostały utracone i teksty zaczęły nabierać cech czysto syntagmatycznych organizacji. Jeśli na poziomie języka naturalnego są one bezspornie obdarzone semantyką, tojako zjawiska kultury ciążą ku syntagmatyce, czyli z tekstów stają się «kodami 2». Tę tendencję mitu do przemieniania się w czysto syntagmatyczny, asemantyczny tekst, nie w komunikat o pewnych zdarzeniach, lecz w schemat organizacji komunikatu miał na myśli Claude Levi-Strauss, mówiąc o jego muzycznej naturze". 
kanon - apokryf oznaczałoby to potencjalną asemantyczność tego pierwszego. Miałby on, zgodnie z tą optyką, ciążyć ku czystej syntagmatyce, co z kolei mogłoby swe źródło mieć w kulturowym dystansie do mitu źródłowego, stającego się już tylko zbiorem kulturowych konwencji i rezerwuarem znaków czekających na ponowne wykorzystanie ${ }^{31}$.

Warto jednak poddać krytycznemu oglądowi te rozstrzygnięcia, okazuje się bowiem, że poddany translacji kanon bynajmniej nie musi stawać się automatycznie „złożonym asemantycznym komunikatem”. Narracje apokryficzne jako nowe komunikaty, kreując nowe sensy, nie likwidują wcale znaczeń pierwotnych - przeciwnie, to właśnie na ich żywotności opierają swoją nowatorskość (a często i profanacyjny czy skandalizujący charakter). Nadto kanon jako tekst wyjściowy opiera się nie na znakach po prostu, lecz na symbolach, a te, by spełniać swoją rolę w nowym komunikacie, muszą pozostawać żywymi, muszą znaczyć.

Symbol, jako „idea pewnej treści, która służy jako plan wyrażenia dla innej, z reguły kulturowo cenniejszej, treści"32, ma, zdaniem Łotmana, podwójną naturę. $\mathrm{Z}$ jednej strony zawiera, w skondensowanej formie, liczne i różnorodne treści, wśród których znaleźć można zawsze „element archaiczny", leżący u korzeni kultury, z drugiej zaś, mimo iż pozostaje w pewnym stopniu skończonym i zamkniętym tworem, z łatwością wchodzi w nowy kontekst tekstowy czy kulturowy. W tym nowym kontekście jednak, zyskując nowe znaczenia, nie traci poprzednich, zachowując semantyczną i strukturalną autonomię 33 .

Nawet w nieortodoksyjnych użyciach symbol aktywizuje własne potencjały znaczeniowe, jest to jednak możliwe tylko wówczas, gdy zachowuje on swoją witalność. To swoiste sprzężenie zwrotne - symbol jest używany, gdyż umożliwia przekaz obszernych i istotnych kulturowo treści, łącząc tym samym przeszłość (tradycję) z teraźniejszością, innymi słowy - jest wykorzystywany, gdyż pozostaje żywy, z drugiej zaś strony jego witalność zależy właśnie od owych nieustannych kulturowych użyć. Jak słusznie zauważa Jan Assmann, tekst, znak lub symbol niekomuni-

31 Tamże, s. 96.

32 Tamże, s. 182.

33 Tamże, s. 183. „[...] z jednej strony, przenikając złoża kultur, symbol realizuje się w swojej inwariantnej postaci. W tym aspekcie możemy obserwować jego powtarzalność. Symbol występować będzie jako coś niejednolitego w stosunku do otaczającej go przestrzeni tekstowej, jako posłaniec innych epok kulturowych (= innych kultur), jako przypomnienie o prastarych (= wiecznych) podstawach kultury. Z drugiej strony, symbol aktywnie koreluje $\mathrm{z}$ kontekstem kulturowym, transformuje się pod jego wpływem i sam go transformuje. Jego inwariantna istota realizuje się w wariantach. Właśnie w tych zmianach, którym ulega «wieczny» sens symbolu w dany m kontekście kulturowym, kontekst ten najwyraźniej ujawnia swoją zmienność". 
kowany powoli wytraca swoją semantykę i osuwa się w przestrzeń kulturowych odpadów ${ }^{34}$. Dlatego też narracje apokryficzne, twórczo/profanacyjnie/nieortodoksyjnie wykorzystujące symbole religijne czerpane $\mathrm{z}$ kanonu, paradoksalnie stają się narzędziem ich (re)witalizacji.

Te transformacje czy reinterpretacje wspierają nadto procesy kulturowej autokomunikacji - mechanizmy niezwykle istotne dla trwania i rozwoju kultury, za ich bowiem sprawą utrzymuje ona kontakt $\mathrm{z}$ tradycją. Łotman wyróżnia dwa podstawowe modele komunikacji. Pierwszy, klasyczny, przebiega w kanale „JA - ON”. „JA” jest podmiotem, nadawcą komunikatu, „ON” zaś przedmiotem, odbiorcą. Treść przekazu jest elementem stałym, zmienia się natomiast nosiciel komunikatu. Byłby to zatem model opisujący raczej zorientowanie na kanon, czyli ścisłe i dokładne przekazanie treści (rozumianych jako objawione). Nadawcą byłaby odpowiednio do kontekstu kulturowego, historycznego i społecznego rozumiana ortodoksja, odbiorcą zaś wspólnota wiernych. W obszarze kontaktów międzykulturowych model ten natomiast opisywałby tendencje uniwersalistyczne nadawcy (jednej kultury), który dąży do narzucania Prawdy wszelkim barbarzyńcom (innym kulturom).

Drugi model, autokomunikacyjny, opiera się na transferze informacji w kanale „JA - JA". Tutaj zmienia się już nie nosiciel komunikatu, lecz sam przekaz, który transformowany jest w czasie, zyskując dodatkowe sensy. Proces ten, jak twierdzi Łotman, prowadzi do przemiany podmio$\mathrm{tu}^{35}$. Ten model oznaczałby zorientowanie na transformację kanonu (jako komunikatu wyjściowego), na twórczy przekład, na przekodowanie źródła $\mathrm{w}$ narrację apokryficzną. Mechanizm ten, jako narzędzie autorefleksji, zapobiega nadmiernemu zdystansowaniu się kultury do własnych korzeni i zerwaniu jej ciągłości. Jest to mechanizm szczególnie istotny w kontekście przemian związanych z globalizacją i upowszechnieniem nowych technologii - w nieustanym kontakcie z Innym kultura Zachodu musi poddawać refleksji swoją tożsamość, czyli również przekazy leżące u jej źródeł.

Procesy autokomunikacyjne wspomagają pracę pamięci kulturowej. Łącząc przeszłość z teraźniejszością, zapobiegają kulturowej amnezji i fragmentaryzacji doświadczenia kulturowego. Pamięć stanowi nie prosty przekaz o „historii samej w sobie”, lecz mechanizm kreowania wizji przeszłości, a tym samym - wizji tego, czym jest dana wyrastająca z niej wspólnota. Dlatego też opiera się na specyficznych nośnikach - mitach i symbolach - a tym samym zawiera pierwiastek sakralny:

34 Por. J. Assmann, Pamięć kulturowa..., s. 106.

35 J. Łotman, Uniwersum umystu..., s. 80-81. 
[prócz symbolu] także mity są figurami pamięci: różnica między mitem a historią zostaje w pamięci kulturowej zawieszona. Dla niej nie liczą się fakty, lecz tylko historia zapamiętana. [...] pamięć kulturowa transformuje historię faktyczną w zapamiętaną, a tym samym w mit. Mit jest historią założycielską, którą się opowiada, aby objaśnić teraźniejszość z perspektywy prapoczątku. [...] W pamięci kulturowej obecny jest pewien element sakralny. Figury pamięci posiadają sens religijny, a uobecnianie ich przez wspominanie ma często charakter święta. [To z kolei sprawia, że] ustanowiona zostaje tożsamość wspominającej grupy ${ }^{36}$.

Mit stanowi medium pamięci z jednej strony przez proces mitologizowania historii, z drugiej zaś przez „uhistorycznianie mitu”, czyli poszukiwanie korzeni wspólnoty i źródeł kultury w mrokach archaiki (w odniesieniu do omawianej problematyki byłoby to coś na kształt kulturowej egzegezy kanonu). Mity i symbole jako nośniki pamięci muszą być nieustannie odczytywane na nowo, dopasowywane do zmieniających się warunków kulturowych i potrzeb wspólnoty. Ta dynamika nie jest jednak zafałszowywaniem źródeł, lecz procesem podtrzymującym witalność kultury, uniemożliwiającym jej skostnienie. Jak zauważa Pierre Nora ${ }^{37}$, dynamiczny charakter pamięci kulturowej pozwala wspólnocie każdorazowo odnajdywać się we własnej przeszłości. To właśnie owa dynamika odróżnia pamięć od specyficznie pojmowanej historiii ${ }^{38}$.

Transformacje mitów i symboli zapobiegają ich osunięciu się w niepamięć. Reinterpretacje te pełnią zatem ważką kulturową rolę, pamięć bowiem funkcjonuje $\mathrm{w}$ dialektycznym sprzężeniu z zapominaniem. Niezliczone treści usuwane są $\mathrm{z}$ kulturowego uniwersum znaczeń $\mathrm{w}$ ramach dbałości o to, co winno być utrzymane w jego centrum. Kultura to (z punktu widzenia semiotyki) sieć znaczeń, wciąż wytwarzanych i przekazywanych sobie przez jej użytkowników. Ta nieustanna semioza musi wspierać się na procesach zapominania, pamięć kultury jest bowiem, mówiąc metaforycznie, ograniczona. Treści istotniejsze z punktu widze-

36 J. Assmann, Kultura pamięci, przeł. A. Kryczyńska-Pham, [w:] Pamięć zbiorowa $i$ kulturowa. Współczesna perspektywa niemiecka, red. M. Saryusz-Wolska, Kraków 2009, s. 84-85.

37 Por. P. Nora, Between Memory and History: Les Lieux de Mémoire, „Representations" nr 26, Special Issue: Memory and Counter-Memory (Spring 1989), s. 7-24.

38 „Specyficznie pojmowanej”, czyli takiej, w ramach której uznaje się pewną trwałość i obiektywność wizji przeszłości. Problem obiektywizmu nauk historycznych podnieśli już jednak narratywiści, zauważając, że są one każdorazowo konstruktem, zależnym od przedzałożeń badacza, który nadto konstruuje własną, usensowniającą przeszłość opowieść, znajdując powiązania między faktami i rekonstruując ( $\mathrm{w}$ swoim mniemaniu) ciągi przyczynowo-skutkowe. Te zindywidualizowane (i zrelatywizowane do tendencji intelektualnych oraz kształtowane przez potrzebę racjonalizacji) narracje nie są $\mathrm{w}$ żadnej mierze „przeszłością samą w sobie”. 
nia danej wspólnoty wypierać muszą te mniej ważne. Często oznaczać to może wypieranie przekazów tradycyjnych, postrzeganych jako archaiczne, przez teksty nowe, waloryzowane dodatnio. $Z$ tego też względu autorefleksyjnie nastawiona współczesna kultura Zachodu staje się kulturą nadpisywania (Aleida Assmann). W jej łonie rodzą się wciąż nowe teksty, interpretujące, przekładające (w znaczeniu Łotmanowskim) czy przekształcające wcześniejsze przekazy. W tym swoistym palimpseście przez warstwę kulturowych nowości prześwituje tradycja. Ten mechanizm znajduje swoje szczególnie intensywne odzwierciedlenie właśnie w zjawisku apokryficzności.

\section{Rekapitulacja}

Jak zatem, w świetle powyższych rozważań, rozumieć można współczesne narracje apokryficzne?

Są to, rzecz jasna, teksty wykorzystujące historie, wątki, postaci i symbole staro- i nowotestamentowe w sposób niezgodny $\mathrm{z}$ ortodoksją (rozumianą tak, jak ją pojmują kościoły chrześcijańskie). Są to również teksty posiłkujące się iluzją fałszerstwa, grające z konwencjami kulturowymi. To wyłącznie stylizacje, które nie mają na celu przekonania odbiorcy o własnej autentyczności (zarówno w znaczeniu rzekomego historycznego, jak i nadprzyrodzonego pochodzenia). To także teksty, które, wchodząc $\mathrm{w}$ intertekstualne relacje zarówno z Pismem Świętym, jak i z innymi, późniejszymi przekazami (nie tylko o tematyce religijnej), ilustrują dystans żywiony przez współczesną kulturę Zachodu do jej własnych mitów źródłowych. To zatem teksty, które, w przeciwieństwie do tradycyjnych apokryfów, uznają zamknięcie kanonu i nie próbują do niego aspirować. Wiąże się to $\mathrm{z}$ ich niesakralnym charakterem - nie są to teksty święte, prawdy objawione. Tematyka religijna służy w nich często do poruszania problemów niereligijnych (krytyka kulturowa, refleksja filozoficzna, rozważania etyczne, debaty polityczne itd.).

Te rozstrzygnięcia nie wyczerpują jednak „fenomenu współczesnej apokryficzności”. By dostrzec inne możliwości nakreślenia panoramy zjawiska, warto odnieść się dodatkowo do nieco odmiennego ujęcia kwestii, zaproponowanego przez Danutę Szajnert w tekście Mutacje apokry$f u^{39}$. Jak każdy badacz mierzący się $\mathrm{z}$ analizowaną kwestią, autorka rozpoczyna swoje rozważania od przywołania rozstrzygnięć Starowieyskiego i Rubinkiewicza, uznaje je jednak, mimo podkreślenia ich istotności, za

39 D. Szajnert, Mutacje apokryfu, [w:] Genologia dzisiaj, red. W. Bolecki, I. Opacki, Warszawa 2000, s. 137-159. 
niepełne. Autorka za kluczową dla swych rozważań uznaje, sproblematyzowaną przez Ryszarda Nycza, „zasadę apokryfu”, która odnosić się ma do działalności pisarskiej i oznaczać „twórcze wyzyskiwanie możliwości odkrytych $\mathrm{w}$ historycznie zinterpretowanym pierwowzorze (poetyce, gatunku, stylu)"40. Zasada ta, częstokroć, jak pisze Szajnert, „dywersyjna” wobec teologicznego rozumienia terminu, inspirować ma przede wszystkim właśnie badaczy literatury i rozszerzać rozumienie apokryficzności na strategie intertekstualne niezwiązane $\mathrm{z}$ wykorzystywaniem biblijnego pierwowzoru. I choć badaczka dostrzega pewne niebezpieczeństwa „nadmiernej tolerancji” dla zrównywania terminu „apokryf” z każdą literacką mistyfikacją, to jednak stawia również opór zbyt ortodoksyjnemu, zawężającemu rozumieniu terminu:

Teologiczne zastrzeżenie nazwy „apokryf” dla niekanonicznych pism okołobiblijnych byłoby równoznaczne $\mathrm{z}$ rezygnacją $\mathrm{z}$ jej etymologiczno-semantycznego potencjału. Już w antyku był on przecież wykorzystywany rozmaicie, co wiązało się ze swoistym uwikłaniem (i zamieszaniem) aksjologicznym. Echa tego uwikłania widoczne są we współczesnych zastosowaniach terminu.

Filologiczno-literaturoznawcze rozszerzenie terminu „apokryf” jedynie na utwory inspirowane fabularnymi wątkami Biblii i apokryfów właściwych oraz „życiem apokryfów” oznaczałoby rezygnację z możliwości, jakie otwiera wyzyskanie relacyjnego względem niego pojęcia kanonu, a zatem i wartości. Wiąże się to m.in. ze zjawiskiem „podłączania się” pod kanon, pozorowania kanonu i z towarzyszącymi temu zjawisku intencjami albo alegacyjnymi, albo destabilizacyjnymi, czy nawet konfrontacyjnymi ${ }^{41}$.

Te intencje jednak związane są raczej, jak już wskazywano, z apokryfami tradycyjnymi czy właściwymi, współczesne narracje apokryficzne nie roszczą sobie bowiem pretensji do tworzenia nowego kanonu, nie aspirują też do kanonu istniejącego. Problematyczne jest $\mathrm{w}$ tym ujęciu również samo rozumienie kanonu. Szajnert wyróżnia rozmaite modele apokryficzności, próbując reinterpretować ujęcia tradycyjne, a raczej rozszerzać je. Dlatego przywołuje w swoim tekście rozumienie apokryfu jako księgi tajemnej, jako tekstu niekanonicznego, jako tekstu literackiego o tematyce biblijnej, w końcu - jako tekstu „niekanonicznego inaczej”. W tym ostatnim przypadku chodzi o poszerzenie pola semantycznego terminu o nawiązania do rozmaitych kanonów, rozumianych już w zlaicyzowanym czy poza-sakralnym sensie. Przykładem mogłyby tu być mity greckie czy twórczość Homera, rozumiane właśnie jako taki zeświecczony kanon - teksty nań się składające to „ludzka biblioteka”, zastępująca

40 Tamże, s. 137.

41 Tamże, s. 138 (pisownia oryginalna). 
„bibliotekę Boską”, to teksty już nie przez Boga dyktowane, lecz przez ludzi, co jednak bynajmniej nie odbiera im kulturowej ważności czy szczególnej wartości. Takie jednak pojmowanie kanonu bliższe jest intuicjom Aleidy Assmann niż przywoływanego tutaj wielokrotnie Jana Assmanna. Dla niemieckiej badaczki kanon to zbiór tekstów kulturowo istotnych, swoistych Bildungstexte, których znajomość niezbędna jest dla prawidłowego funkcjonowania jednostki w danej kulturze. Jan Assmann z kolei tego typu teksty określa mianem klasyki, pojęcie kanonu rezerwując wyłącznie dla tekstów świętych (a i to - nie dla wszystkich). Uważam podejście niemieckiego myśliciela za bardziej pomocne $\mathrm{w}$ analizach kulturoznawczych, pozwala ono bowiem odróżnić dwa bloki kulturowo istotnych tekstów, z których te kanoniczne są bardziej archaiczne, bardziej zamknięte na ingerencje i zarazem otwarte na egzegezę. Poszerzenie rozumienia apokryfu i zarazem kanonu jest, rzecz jasna, interesującym pomysłem, będącym niewątpliwie strategią heurystycznie płodną w obszarze badań literackich, zwłaszcza zaś w sferze analizy relacji intertekstualnych, w obszarze refleksji kulturoznawczej jednak może być zabiegiem zaciemniającym czy zamazującym obraz współczesnej apokryficzności. Apokryficzność jest bowiem, co należy z całą mocą podkreślić, zjawiskiem nie tylko literackim, ale i kulturowym właśnie, i jako taka lepiej zrozumiana być może w powiązaniu z rozumieniem kanonu przez Jana Assmanna, a także z Łotmanowskim postrzeganiem tekstów kanonicznych jako jądra kultury, jako czegoś w pewnym sensie archaicznego, bo powiązanego z symbolem (który, jak już wskazywano, stanowi podstawowe medium pamięci kulturowej). Ujęcie proponowane przez Szajnert jest zatem interesujące, ale niekoniecznie funkcjonalne dla refleksji kulturoznawczej. Zwłaszcza że badaczka dalej rozszerza interesujące ją pojęcie o nawiązania do kanonu rozumianego jako wzorzec czy ideał, a składającego się z pewnych typów czy gatunków tekstów niefikcyjnych (listy, pamiętniki, wyznania) ${ }^{42}$. Wówczas za apokryf uznać można na przykład opowieść o Robinsonie Crusoe czy podróżach Gulliwera, opisy przygód Moll Flanders czy epistolarne Niebezpieczne związki. Tego typu rozszerzenie znaczeniowe terminu, pozostające jedną $\mathrm{z}$ wielu strategii redefiniowania czy pogłębiania semantycznego zakresu pojęcia, prowadzić może do konkluzji, do której autorka nie całkiem się może przychyla, ale i przed którą nie do końca się wzbrania: „efektem takiej konstrukcji mogłaby być, nie całkiem przecież bezpodstawna, formuła w rodzaju: «wszystko jest apokryfem»"43.

42 Tamże, s. 150.

43 Tamże, s. 158. 
Szajnert wyróżnia takie „rodzaje kanonów”, jak Pismo Święte, mit, tekst literacki oraz autentyczny tekst niefikcyjny. Apokryficzność miałaby się z kolei zasadzać na jednej z dwóch strategii: pierwszą jest wykorzystanie potencjału semantycznego terminu (chodzi tu przede wszystkim o kwestię „ukrycia”), drugą natomiast zasada konstrukcji (odniesienie właśnie do tak czy inaczej rozumianego kanonu). Możliwe są nadto, jak zastrzega badaczka, rozmaite kombinacje, reinterpretacje czy mutacje (stąd wywodzą się choćby wskazywane przez nią „,apokryfy trzeciego rzędu"). Są to rozwiązania z pewnością interesujące i płodne w obszarze swoistej „taksonomii literatury”, ale dla badań kulturoznawczych są one nie zawsze przydatne, te bowiem zasadzają się na analizach dotyczących pewnych kulturowych mechanizmów o wyższym stopniu ogólności (jak wspomniane mechanizmy autokomunikacji, transformacji symbolu, konstruowania i pielęgnowania pamięci kulturowej) - procesy intertekstualne odgrywają tutaj ważką rolę, nie można jednak do nich tylko ograniczać analiz. Szajnert podkreśla, że „przymierzanie i przykrawanie poszczególnych autorskich wyborów do jakiejś jednolitej, ustalonej przez nas z góry, wizji «światopoglądu» apokryfu grozi zafałszowaniem przedmiotu"44. Badaczka z pewnością ma tutaj wiele racji. Niniejszy tekst, będący próbą kulturoznawczego oglądu zjawiska współczesnej apokryficzności z pewnością zasadza się właśnie na pewnym ograniczaniu i przykrawaniu terminu ,apokryf” do potrzeb prowadzonych tu analiz. Pragnę jednak zauważyć, że jest to wyłącznie pewna forma idealizacji, którą postrzegam jako heurystycznie płodną, nie zaś próba „absolutyzowania” zawartych tu rozstrzygnięć. Przypisanie terminu „apokryf” wyłącznie do tekstów nawiązujących do Biblii, czyli kanonu w rozumieniu Jana Assmanna, służyć ma wydobyciu na powierzchnię pewnych mechanizmów związanych ze wspomnianym symbolem religijnym, takich jak twórczy przekład, komunikacja w systemie „JA - JA” czy pielęgnowanie tożsamości kulturowej. Nie musi zawężenie to oznaczać zatem ostatecznego zamknięcia zbioru apokryfów na teksty wspomniane przez Szajnert - podjęta tu przeze mnie próba dookreślenia pojęcia apokryfu służyć ma bowiem wyłącznie analizie roli, jaką pewnego typu teksty odgrywają we współczesnej kulturze Zachodu.

Ze względu na tę właśnie rolę narracje apokryficzne można zatem, jak wspomniano, rozumieć również jako:

1) efekt twórczego przekładu jednego tekstu na drugi, a także przekładu jednego systemu semiotycznego na inny (sacrum na profanum),

44 Tamże, s. 154. 
2) komunikat oparty na kodzie tekstu prymarnego, czyli kanonu. Pismo Święte zostaje w obszarze „apokryfów” zreinterpretowane za sprawą przesunięcia od semantyki do syntagmatyki, to jest od komunikatu do kodu, co wprawdzie stanowi element profanacji, zarazem służy jednak przyrostowi semiotycznych potencjałów kanonu,

3) narzędzie autokomunikacji kultury (komunikat w schemacie ,JA - JA"),

4) instrument metarefleksji kulturowej,

5) narzędzie (re)witalizacji symbolu,

6) medium pamięci kulturowej.

Powyższa szkicowa charakterystyka nie jest z pewnością wyczerpująca, sądzę jednak, że w jakimś stopniu przybliża najistotniejsze cechy współczesnej apokryficzności. Analiza poszczególnych współczesnych nieortodoksyjnych użyć kanonicznych symboli (na którą niestety w tak krótkim tekście nie można sobie pozwolić) umożliwia ogląd najważniejszych mechanizmów scalających kulturowe uniwersum znaczeń i wspomagających procesy uspójniania zbiorowej tożsamości. Pozwala to również na dostrzeżenie rozmaitych przemian, którym podlega kultura Zachodu, nie tylko w obszarze religijności.

\section{BIBLIOGRAFIA}

Apokryfy Nowego Testamentu. Ewangelie apokryficzne, część I Fragment. Narodzenie i dzieciństwo Maryi i Jezusa, red. M. Starowieyski, Kraków 2003.

Assmann J., Pamięć kulturowa. Pismo, zapamiętywanie i polityczna tożsamość $w$ cywilizacjach starożytnych, przeł. A. Kryczyńska-Pham, Warszawa 2008.

Assmann J., Kultura pamięci, przeł. A. Kryczyńska-Pham, [w:] Pamięć zbiorowa $i$ kulturowa. Wspótczesna perspektywa niemiecka, red. M. Saryusz-Wolska, Kraków 2009.

Balbus S., Między stylami, Kraków 1993.

Beskow P., Osobliwe opowieści o Jezusie. Analiza nowych apokryfów, przeł. J. Wolak, wstęp M. Starowieyski, Kraków 2005.

Draaisma D., Machina metafor. Historia pamięci, przeł. R. Pucek, Warszawa 2009.

Kamieńska A., Twarze księgi, Warszawa 1982.

Łotman J., Uniwersum umystu. Semiotyczna teoria kultury, przeł. B. Żyłko, Gdańsk 2008.

Nora P., Between Memory and History: Les Lieux de Mémoire, „Representations” nr 26, Special Issue: Memory and Counter-Memory (Spring 1989), s. 7-24.

Rahner K., Vorgrimler H., Mały słownik teologiczny, przeł. T. Mieszkowski, P. Pachciarek, Warszawa 1987. 
Ricoeur P., LaCocque A., Myśleć biblijnie, przeł. E. Mukoid, M. Tarnowska, Kraków 2003.

Rubinkiewicz R., Wprowadzenie do apokryfów Starego Testamentu, Lublin 1987.

Starowieyski M., Barwny świat apokryfów, Poznań 2006.

Szajnert D., Mutacje apokryfu, [w:] Genologia dzisiaj, red. W. Bolecki, I. Opacki, Warszawa 2000. 